INDONESIA ACCOUNTING JOURNAL

VOLUME 3, NUMBER 1, YEAR 2021

${ }^{1}$ Corresponding author

Accounting Programme

Muslim Indonesia University

Jl. Urip Sumohardjo KM 5

Makassar, South Sulawesi Province,

Indonesia, 90231

E-mail: muharsyad@umi.ac.id

${ }^{2}$ Accounting Programme

Muslim Indonesia University

Jl. Urip Sumohardjo KM 5

Makassar, South Sulawesi Province,

Indonesia, 90231

${ }^{3}$ Accounting Programme

Muslim Indonesia University

Jl. Urip Sumohardjo KM 5

Makassar, South Sulawesi Province,

Indonesia, 90231

${ }^{4}$ Accounting Programme

Muslim Indonesia University

Jl. Urip Sumohardjo KM 5

Makassar, South Sulawesi Province,

Indonesia, 90231

Article info:

Received 30 October 2020

Accepted 7 April 2021

Available online 8 April 2021

Keywords: TATO; CR; ROI; DPR; signaling; residual cash

JEL Classification: G11, G34, G35

DOI: http://doi.org/10.32400/iaj.30119

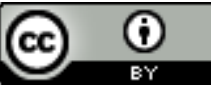

This work is licensed under a Creative

Commons Attribution 4.0

International License.

\section{The effect of activity ratios, liquidity, and profitability on the dividend payout ratio?}

\author{
Muhammad Arsyad ${ }^{1}$ \\ Sitti Hartati Haeruddin ${ }^{2}$ \\ Muslim ${ }^{3}$ \\ Muhammad Faisal A. R. Pelu ${ }^{4}$
}

\begin{abstract}
Dividends are a significant factor in investors' investment interests, so that dividend policy is a critical factor for companies to retain their shareholders. On this purposes, the companies must improve financial performance, especially activity ratios, liquidity ratios, and profitability ratios in this condition. The consumer goods industry sector is one of the industries that play a significant role in the capital market as they have rapid business competition. Until May 2020, the performance condition of companies in the consumer goods industry was experiencing less than optimal conditions as the manufacturing sector weakened at $\mathbf{2 2 . 0 \%}$ due to the weakening of Indonesia's manufacturing Purchasing Managers' Index (PMI). The condition indicates that the impact of a decrease in the company's liquidity performance is a decrease in demand for manufactured goods which gives results in a decrease in profitability performance, and a less than optimal turnover of company assets in the consumer goods industry sector. This study uses manufacturing companies in the consumer goods industry listed on the Indonesia Stock Exchange from 2015 to 2019 as a sample. Multiple regression analysis results show that return on investment has a positive and significant effect on the dividend payout ratio. This result implies that the profitability ratio is a positive signal for investors in the capital market regarding the company's dividend policy.
\end{abstract}

\section{Introduction}

Manufacturing companies in the consumer goods industry sector are one of the industries that significantly influence trade dynamics in the capital market (Arlita et al., 2019). This trading dynamic is triggered by the consumer goods industry's business competition, which demands an increase in company value among its competitors (Kombih \& Suhardianto, 2017). To improve performance, management will formulate a business strategy that will determine the direction of the company's business development (Wheelen et al., 2018:44). The company's business development requires a large enough amount of working capital to allow internal funds to be insufficient for working capital needs (Pontoh, 2018). This causes a company to attract investors to invest in its business to increase its working capital (Dewi et al., 2017). The performance condition of companies in the consumer goods industry until May 2020 was experiencing less than optimal conditions as the manufacturing sector weakened at 
$22.0 \%$ due to the weakening of Indonesia's manufacturing Purchasing Managers' Index (PMI), which was at its lowest level since 2011 (Badan Kebijakan Fiskal, 2020). This indicates the impact of a decrease in the company's liquidity performance, a decrease in demand for manufactured goods, a decrease in profitability performance, and a less than optimal turnover of company assets in the consumer goods industry sector.

In general, investors' capital is used to run company operations (Panggabean \& Martin, 2020). The capital market is an important medium for investors to invest in order to provide optimal returns in the form of dividend income or capital gains (Hanif \& Bustamam, 2017). The choice of dividends and capital gains depends on the needs and goals of investors (Lucyanda \& Lilyana, 2012). Raza et al. (2018) prove that investors' expectations and preferences tend to be closely related to dividend policy because dividends are considered to have certainty compared to capital gains. A dividend policy is a decision whether the profits earned by the company will be distributed to shareholders as cash dividends or will be retained in the form of retained earnings for future investment financing (Sartono, 2001:101; Van Horne \& Wachowicz, 2008:476). Dividend policy tends to inform investors that management has managed capital well to produce the expected profit (Deitiana, 2013). Nurdin et al. (2019) show that the amount of dividends distributed is based on profits achieved by considering the company's investment interests. Decisions on dividend distribution also need to consider its survival and growth (Muhammadinah \& Jamil, 2015; Prabulana et al., 2017). Managers believe that a decrease in dividend payments will be viewed negatively by shareholders (Rafaizan et al., 2020). Arumbarkah and Pelu (2019) prove that a decrease in dividends tends to give investors wrong signals in the capital market.

A business organization consists of two interested parties, namely shareholders and management, where the dividend policy tends to cause internal conflicts between the two parties (Jensen \& Meckling, 1976; Purwanti \& Sawitri, 2011). Internal conflicts tend to be caused by management's aim to hold profits in the interests of investment to increase company growth, and vice versa shareholders expect that profits are distributed in the form of high dividends based on the proportionate share ownership they have (Ningrum, 2017). Dividend policy is closely related to companies' funding decisions because the dividend payout ratio has implications for retained earnings, one of the company's funding sources. Meaning that the greater the value of profits retained by the company, the less the amount of profit allocated to dividend payments (Puspita, 2017).

Empirically, dividend policy can be influenced by the activity ratio, liquidity ratio, and profitability ratio. Sulaiman and Sumani (2016), and Firdaus and Handayani (2019) empirically prove that the activity ratio is a determinant of public companies' dividend policy. Also, Sarmento and Dana (2016) and Wardani et al. (2018) prove that the liquidity ratio is a determinant of dividend policy in public companies. Yuliyanti and Nurhasanah (2013), and Wijaya and Sedana (2015) also prove that profitability is an essential factor in increasing dividends distributed to shareholders. This study aims to determine the effect of activity ratios, liquidity ratios, and profitability ratios on dividend policy in public companies, especially in the consumer goods industry sector listed on the Indonesia Stock Exchange (IDX), to provide consideration for management policies and the manufacturing industry business sector related to harmonization of company operations with the interests of stockholders.

\section{Literature review}

\section{Signaling theory}

The signal theory states that dividend payments are a signal to outside investors regarding the company's prospects. Companies that pay dividends will show that the company has reasonable expectations 
for the future (Adnan et al., 2014). In the context of dividend policy, dividend distribution is a signal for investors, thereby reducing information asymmetry (Sejati et al., 2020). The increase in dividends is a signal for investors who predict the company's future earnings will be in better condition so that dividend distribution will increase investment confidence for investors (Salsabilla \& Isbanah, 2020). This study uses activity ratios, liquidity ratios, and profitability ratios to test whether these three ratios are signals for dividend policy.

\section{The residual theory of cash dividends}

The residual of cash dividends theory states that a business entity pays dividends only if the company has excess funds over its profits used to finance planned projects (Adnan et al., 2014). However, the distribution of significant dividends is less favored by management because it reduces management utility due to the smaller amount of funds that are within the scope of management's control so that management tends to impose retained earnings or reinvest it in investments with negative net present value to benefit management (Jensen \& Meckling, 1976). Consistently, Kaen (2003) states that the excess cash should be distributed in dividends even though the management does not like the distribution of profits obtained in dividends. Consistent with Laili et al. (2015), this study uses liquidity ratios and profitability ratios to test whether these two ratios are excess cash factors that affect dividend policy.

\section{Hypothesis development}

\section{Activity ratios and dividend policy}

The company's activity ratio conceptually refers to the asset management ratio, which aims to measure how the company manages its assets effectively in generating profits (Brigham \& Ehrhardt, 2017:106). This indicates that the activity ratio is one of the determinants of dividend policy through sound asset management. Rahayuningtyas (2014), Sulaiman and Sumani (2016), and Firdaus and Handayani
(2019) prove empirically that the activity ratio determines the dividend policy of public companies. This study uses Total Assets Turn Over (TATO) as an indicator of activity ratios. The more excellent TATO value indicates a faster asset turnover so that the company can achieve profit while at the same time showing the efficiency of asset utilization in generating sales (Putry \& Erawati, 2013). The large TATO value also tends to cause management to choose to hold profits for the benefit of future expansion investments or choose dividend distribution if management considers that the profits earned will not be invested according to the residual theory of cash dividends. Based on the existing assumptions, the formulation of the research hypothesis is presented below.

H1: The activity ratio has a positive and significant effect on dividend policy

\section{Liquidity ratio and dividend policy}

The liquidity ratio refers to the concept of how far the company's assets are available in completing its obligations (Brigham \& Ehrhardt, 2017:104). Business liquidity depends on the organization's ability to convert its assets into cash to meet current liabilities or other liabilities (Ahmed, 2015). In the context of the dividend signal theory, this indicates that companies with higher cash availability tend to pay more significant dividends than companies with low levels of liquidity (Kaźmierska-Jóźwiak, 2015). This study uses the Current Ratio (CR) as an indicator of the liquidity ratio. Sarmento and Dana (2016), Wahyuni and Hafiz (2018), and Wardani et al. (2018) prove that the liquidity ratio is a determinant of dividend policy in public companies. In contrast, Muhammadinah and Jamil (2015), Rahayu and Hari (2016), and Astiti et al., (2017) prove that the liquidity ratio with the CR indicator did not significantly affect the dividend policy of the public companies. Based on the existing assumptions, the formulation of the research hypothesis is presented below.

H2: The liquidity ratio has a positive and significant effect on dividend policy 
Profitability ratios and dividend policy

Profitability is the net result obtained based on policies and decisions where this ratio and providing information on the company's operational effectiveness are also the combined impact of liquidity, asset management, and debt on operating results (Brigham \& Ehrhardt, 2017:114). Profitability provides an overview of the company's ability to generate profits and a basis for consideration in making decisions about dividend policy (Salsabilla \& Isbanah, 2020). In the context of signal theory, dividend distribution is a signal for the prospects of the company so that it requires large cash inflows to increase profits which will have an impact on increasing the proportion of profits to be distributed as dividends (Pontoh, 2015; Fitri et al., 2016). This study uses the Return on Investment (ROI) as an indicator of the profitability ratio. Hadiwidjaja and Triani (2009), Yuliyanti and Nurhasanah (2013), Wijaya and Sedana (2015), and Khan and Ahmad (2017) prove that profitability has a positive and significant effect on dividend policy. Based on the existing assumptions, the formulation of the research hypothesis is presented below.

H3: Profitability ratio has a positive and significant effect on dividend policy

\section{Research methods}

The type of this study is a quantitative approach with an associative method. According to Kuncoro (2009:211), the associative test is a study that aims to determine the relationship between two or more variables, as well as the correlation between the variables studied. The type of data in this study is quantitative data in the form of processing numbers sourced from financial reports. The data collection technique in this research is in the form of a documentation study where data is obtained through published financial reports from companies listed on the IDX, which are the object of this research. Table 1 presents the sample determination based on predetermined criteria from this study population, namely manufacturing companies in the consumer goods industry sector listed on the IDX in the period 2015 to 2019 .

Table 1. Sampl

\begin{tabular}{lc}
\hline \multicolumn{1}{c}{ Criteria } & Amount \\
\hline $\begin{array}{l}\text { The number of objects registered on the } \\
\text { capital market during the observation period } \\
\text { Total object did not publish regular financial } \\
\text { reports during the observation period }\end{array}$ & 53 \\
$\begin{array}{l}\text { The number of objects does not distribute } \\
\text { dividends in the observation period }\end{array}$ & $(30)$ \\
$\begin{array}{l}\text { The number of objects as samples in the } \\
\text { observation period }\end{array}$ & 14 \\
The samples in the observation period & 70 \\
\hline
\end{tabular}

Consistent with Salsabilla and Isbanah (2020), this study uses the Dividend Payout Ratio (DPR) as the dependent variable calculated by the ratio of dividend per share ratio over earnings per share. The independent variables in this study can be described as follows.

- Total Assets Turn Over (TATO), measured using the ratio of sales to total assets. Consistent with Deitiana (2013), TATO is a ratio that informs the effectiveness of the company in managing its assets to increase sales in optimizing profit.

- The current Ratio (CR) is measured using the ratio of current assets to current liabilities. Consistent with Kieso et al. (2018:332), CR is a ratio that measures the company's ability to complete short-term obligations.

- Return on Investment (ROI), measured using the ratio of net profit after tax to total assets. Consistent with Harahap (2013:169), ROI shows the amount of net income obtained from all assets owned by the company or reflects the level of company profits on the use of its assets.

This study uses multiple regression analysis at a significance level of $5 \%$ with the following stages.

- Classic assumption test, which consists of normality test, multicollinearity test, and heteroscedasticity test. The normality test aims to test whether, in the regression model, the dependent variable and the independent variable both have a normal distribution or not because a good regression model has a normal or nearnormal data distribution (Ghozali, 
2005:110). The multicollinearity test aims to test whether the regression model finds a correlation between independent variables using the tolerance value and Variance Inflation Factor (VIF). If the tolerance value is above 0.1 or the VIF value is below 10 , multicollinearity does not occur (Ghozali, 2005:91). The heteroscedasticity test aims to determine whether the regression model used is inequality of variants from the residuals of another observation (Ghozali, 2005:105).

- The correlation coefficient and determination, where the correlation value $(\mathrm{R})$ is used to measure the relationship between the dependent variable and the independent variable (Ghozali, 2005:82). The value of determination or $\mathrm{R}$ square $\left(\mathrm{R}^{2}\right)$ aims to measure the extent to which the model's ability to explain variations in the dependent variable where the value of $\mathrm{R}^{2}$ is in the range of zero and one values so that the small $\mathrm{R}^{2}$ value means that the ability of the independent variable to explain variations in the dependent variable is minimal and vice versa if it approaches. The value of one means the independent variable provides the information needed to predict all the dependent variables (Ghozali, 2005:83).

- Model feasibility test or F test aims to test the feasibility of the model in the sense that if there is a simultaneous influence between the independent variable on the dependent variable (Ghozali, 2005:83).

- The significance test or t-test, or partial test, aims to determine how far the influence of one explanatory variable individually explains the dependent variable's variation. The basis for decisionmaking is to compare the $\mathrm{t}$ value with the $\mathrm{t}$ table (Ghozali, 2005:84).

The regression equation for hypothesis testing can be formulated as follows.

$$
D P R=\alpha+\beta . T A T O+\beta . C R+\beta . R O I+\varepsilon
$$

\section{Result and discussion}

\section{Results}

Descriptive statistics. Table 2 shows that TATO has an average value of 1.2223 with a minimum value of 0.55 , a maximum value of 2.42 , and a standard deviation of 0.42340 . The analysis also shows that CR has an average value of 2.6501 with a minimum value of 0.51 , a maximum value of 8.64 , and a standard deviation of 1.79019 . ROI has an average value of 0.1911 with a minimum value of -0.03 , a maximum value of 1.00 , and a standard deviation of 0.20933 . Furthermore, the DPR has an average value of 0.5219 with a minimum value of 0.11 , the maximum value obtained is 1.46 , and a standard deviation value of 0.28541 .

Table 2. Descriptive statistics

\begin{tabular}{lccccc}
\hline & N & Minimum & Maximum & Mean & $\begin{array}{c}\text { Std. } \\
\text { Deviation }\end{array}$ \\
\hline DPR & 70 & 0.11 & 1.46 & 0.5219 & 0.28541 \\
TATO & 70 & 0.55 & 2.42 & 1.2223 & 0.42340 \\
CR & 70 & 0.51 & 8.64 & 2.6501 & 1.79019 \\
ROI & 70 & 0.03 & 1.00 & 0.1911 & 0.20933 \\
Valid N & 70 & & & & \\
(listwise) & & & & & \\
\hline
\end{tabular}

Classic assumption test. Figure 1 shows the data normality test in this study by looking at the normal probability plot, and it can be concluded that the residual data error is normally distributed.

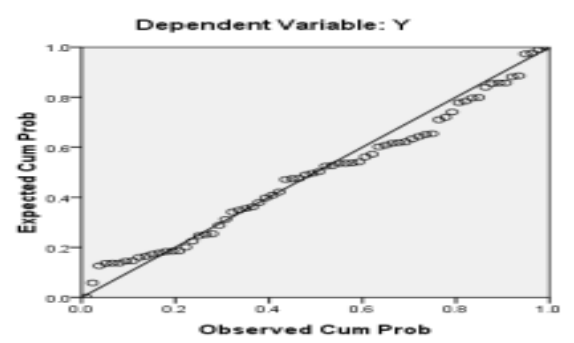

Figure 1. Normality test

Figure 2 shows that the scatterplot graph does not have a clear pattern. The dots spread randomly above and below the number 0 on the $\mathrm{Y}$ axis, so it can be concluded that there is no heteroscedasticity problem in this study.

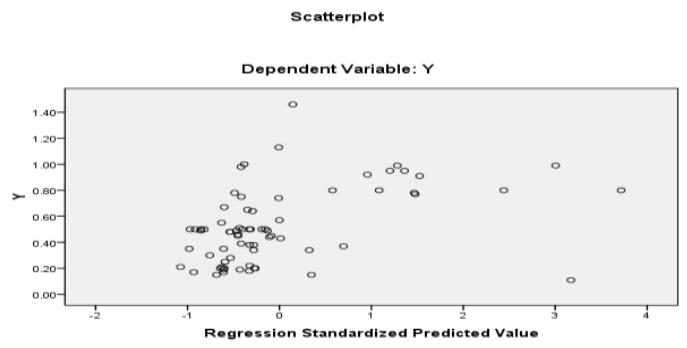

Figure 2. Heteroscedasticity test 
Table 3 shows that all independent variables have a tolerance value of more than 0.1 and a Variance Inflation Factors (VIF) value of less than 10 , so it can be concluded that there are no multicollinearity symptoms between the independent variables.

Correlation coefficient and determination. Table 3 shows that the $\mathrm{R}$-value is 0.427 or $42.7 \%$, which means that TATO, CR, and ROI have a relationship with the DPR. The value of $R$ square $\left(R^{2}\right)$ obtained is 0.182 or $18.2 \%$, which means that the variation of TATO, CR, and ROI is limited in explaining DPR because $81.8 \%$ can be explained by other factors not included in this research model.

Fit model test. Table 3 shows that the calculated $F$ value is 4.893 with less than 0.05 , so it can be concluded that the regression model is fit and TATO, CR, and ROI simultaneously affect the DPR.

Significance test. Table 3 shows that partially TATO and CR are not significant to the DPR, so $\mathrm{H} 1$ and $\mathrm{H} 2$ are rejected. On the other hand, ROI is partially significant against DPR with a positive coefficient so that $\mathrm{H} 3$ is accepted. The regression test results of this study show the regression model or equation as follows.

$D P R=0.329+0,063 . T A T O+0,005 . C R+0,534 . R O I+\varepsilon$

\begin{tabular}{|c|c|c|c|c|c|}
\hline \multirow{2}{*}{$\begin{array}{l}\text { Independent } \\
\text { variables }\end{array}$} & \multicolumn{2}{|c|}{$\begin{array}{l}\text { Unstandardized } \\
\text { Coefficients }\end{array}$} & \multirow{2}{*}{ t } & \multicolumn{2}{|c|}{$\begin{array}{l}\text { Collinearity } \\
\text { Statistics }\end{array}$} \\
\hline & B & $\begin{array}{l}\text { Std. } \\
\text { Error }\end{array}$ & & Tolerance & VIF \\
\hline Constant & 0.329 & 0.139 & 2.368 & & \\
\hline TATO & 0.063 & 0.089 & 0.715 & 0.716 & 1.396 \\
\hline CR & 0.005 & 0.020 & 0.252 & 0.784 & 1.275 \\
\hline ROI & $0.534 *$ & 0.160 & 3.333 & 0.897 & 1.115 \\
\hline$F$ test & $4.893 *$ & & & & \\
\hline $\mathrm{R}$ & 0.427 & & & & \\
\hline R2 & 0.182 & & & & \\
\hline Adj. R2 & 0.145 & & & & \\
\hline
\end{tabular}

\section{Discussions}

\section{Activity ratios and dividend policy}

This study proves that TATO is not significant for the DPR. This indicates that signal theory cannot be applied to dividend policy from asset management or TATO. Signal theory explains that companies should be able to provide signals to users of financial statements, especially investors, to invest in relation to dividend payouts.
Investors consider that an increase in dividends will be considered a positive signal, which means that the company has good prospects, resulting in a positive reaction. The results of this study are inconsistent with Putry and Erawati (2013), Rahayuningtyas (2014), Sulaiman and Sumani (2016), and Firdaus and Handayani (2019).

\section{Liquidity ratio and dividend policy}

This study proves that CR is not significant for the DPR. This indicates that signal theory cannot be applied to dividend policy from a liquidity or CR perspective. The results of this study assume that if the CR increases, the DPR value will decrease in value to give an unfavorable signal to investors. Conversely, the results of this study are still consistent with the residual of cash dividends with the assumption that the company will only pay dividends if the company has certainty predictions that profits are at the threshold for future investment needs so that the excess on profits can be distributed to investors in the future. Form of a dividend. This study is inconsistent with Sarmento and Dana (2016), Wahyuni and Hafiz (2018), and Wardani et al. (2018) but otherwise consistent with Muhammadinah and Jamil (2015), Rahayu and Hari (2016), and Astiti et al. (2017).

\section{Profitability ratios and dividend policy}

This study proves that ROI has a significant and positive effect on the DPR. This means that the higher the company's ROI value, the higher the DPR value obtained by investors. The results of this study also indicate that signal theory can be applied to dividend policy from the perspective of profitability or ROI. Signal theory explains that financial statements that generate high profitability will provide good investors' signals in terms of dividend distribution. This study is consistent with Hadiwidjaja and Triani (2009), Yuliyanti and Nurhasanah (2013), Wijaya and Sedana (2015), and Khan and Ahmad (2017) in proving that profitability is the main 
determining factor for the dividend policy of public companies.

\section{Conclusion}

This study provides empirical evidence that ROI is a significant determinant of dividend policy besides TATO and CR. This study also proves that signal theory is consistent with dividend policy from a profitability point of view. This study suggests that investors should enrich their knowledge of information circulating in the capital market and increase their understanding of financial statements to avoid mistakes in making decisions to invest. Information on the value of ROI can be used as investment consideration for investors interested in profits in the form of dividends. This study also suggests that companies optimize information disclosure on policies taken to use the information needed to avoid pessimistic reactions from investors in the capital market. Further studies are expected to conduct a deeper study of the DPR by adding other variables to the cash position, company size, company growth, net profit margin, interest rates, and tax rates and can use other industrial sectors or increase observation.

\section{Data availability}

The research data can be accessed openly in the supporting document of the article (supplementary file).

\section{References}

Ahmed, I. E. (2015). Liquidity, profitability and the dividends payout policy. World Review of Business Research, 5(2), 73-85. https://www.researchgate.net/publication/336871 172 Liquidity Profitability and the Dividends P ayout Policy

Adnan, M. A., Gunawan, B., \& Candrasari, R. (2014). Pengaruh profitabilitas, leverage, growth, dan free cash flow terhadap dividend payout ratio perusahaan dengan mempertimbangkan corporate governance sebagai variabel intervening. Jurnal Akuntansi dan Auditing Indonesia, 18(2), 89-100. https://doi.org/10.20885/jaai.vol18.iss2.art1

Arlita, R., Bone, H., \& Kesuma, A. I. (2019). Pengaruh good corporate governance dan leverage terhadap praktik manajemen laba pada perusahaan manufaktur sektor industri barang konsumsi yang terdaftar di Bursa Efek Indonesia (BEI).
AKUNTABEL: Jurnal Akuntansi dan Keuangan, 16(2), 238-248.

http://journal.feb.unmul.ac.id/index.php/AKUN TABEL/article/view/6113

Arumbarkah, A. M., \& Pelu, M. F. A. (2019). Pengaruh likuiditas, profitabilitas, leverage dan growth terhadap kebijakan dividen dengan ukuran perusahaan sebagai variabel moderating. CESJ: Center of Economic Students Journal, 2(2), 21-36. https://jurnal.fe.umi.ac.id/index.php/CESJ/article $\angle$ view/177

Astiti, N. A., Yuniarta, G. A., \& Sujana, E. (2017). Pengaruh Debt to Equity Ratio (DER), Current Ratio (CR), Net Present Margin (NPM), Return on Asset (ROA), terhadap Dividend Payout Ratio (DPR): Studi pada perusahaan basic industry dan properti, real estate \& building contruction yang terdaftar di Bursa Efek Indonesia periode 20112015. Jurnal Ilmiah Mabasiswa Akuntansi Undiksha, 7(1), 1-12. https://ejournal.undiksha.ac.id/index.php/S1ak/ar ticle/view/9375

Badan Kebijakan Fiskal. (2020). Tinjauan ekonomi, keuangan dan fiskal. https://fiskal.kemenkeu.go.id/publikasi/tinjauanekonomi-keuangan-dan-fiskal

Brigham, E. F., \& Ehrhardt, M. C. (2017). Financial management: Theory and practice, $15^{\text {th }}$ Edition. United States: Cengage Learning.

Deitiana, T. (2013). Pengaruh current ratio, return on equity dan total asset turn over terhadap dividend payout ratio dan implikasi pada harga saham perusahaan LQ 45. Jurnal Bisnis dan Akuntansi, 15(1), 82-88. https://jurnaltsm.id/index.php/JBA/article/view/ 249

Dewi, N. S. R. T., Adnantara, K. F., \& Asana, G. H. S. (2017). Modal investasi awal dan persepsi risiko dalam keputusan berinvestasi. Jurnal Ilmiah Akuntansi, $\quad 2(2), \quad$ 173-190. http://dx.doi.org/10.23887/jia.v2i2.15636

Firdaus, I., \& Handayani, P. (2019). Pengaruh DER, TATO dan NPM terhadap kebijakan dividen (Studi kasus pada industri dasar dan kimia yang terdaftar di Bursa Efek Indonesia (BEI) tahun 2012-2016). Journal of Applied Accounting and Finance, 3(1), 71-84. http://dx.doi.org/10.33021/jaaf.v3i1.679

Fitri, R. R., Hosen, M. N., \& Muhari, S. (2016). Analysis of factors that impact dividend payout ratio on listed companies at Jakarta Islamic Index. International Journal of Academic Research in Accounting, Finance and Management Sciences, $\quad 6(2), \quad$ 87-97. http://dx.doi.org/10.6007/IJARAFMS/v6i2/2074

Ghozali, I. (2005). Analisis Multivariate dengan program SPSS. Semarang: Badan Penerbit Universitas Diponegoro.

Hadiwidjaja, R. D., \& Triani, L. F. (2009). Pengaruh profitabilitas terhadap dividend payout ratio pada perusahaan manufaktur di Indonesia. Jurnal Organisasi dan Manajemen, 5(1), 49-54. https://jurnal.ut.ac.id/index.php/jom/article/view $\not 214$

Hanif, M., \& Bustamam. (2017). Pengaruh debt to equity ratio, return on asset, firm size, dan earning pe share terhadap dividend payout ratio (Studi pada perusahaan manufaktur yang terdaftar di Bursa Efek Indonesia tahun 2011-2015). Jurnal Ilmiah 
Mahasiswa Ekonomi Akuntansi, 2(1), 73-81. http://www.jim.unsyiah.ac.id/EKA/article/view/ 2222

Harahap, S. S. (2013). Analisis kritis atas laporan keuangan, Edisi 11. Jakarta: Rajawali Pers.

Jensen, M. C., \& Meckling, W. H. (1976). Theory of the firm: Managerial behavior, agency costs and ownership structure. Journal of Financial Economics, 3(4), 305-360. https://doi.org/10.1016/0304405X(76)90026-X

Kaen, F. R. (2003). A blueprint for corporate governance: A strategy, accountability, and the preservation of shareholder value. United States: AMACOM

Kaźmierska-Jóźwiak, B. (2015). Determinants of dividend policy: Evidence from Polish listed companies. Procedia Economics and Finance, 23, 473-477. https://doi.org/10.1016/S2212-5671(15)00490-6

Khan, F. A., \& Ahmad, N. (2017). Determinants of dividend payout: An empirical study of pharmaceutical companies of Pakistan Stock Exchange (PSX). Journal of Financial Studies \& Research,

1-16. https://doi.org/10.5171/2017.538821

Kieso, D. E., Jerry, J. W., \& Terry, D. W. (2018). Akuntansi keuangan menengah. Jakarta: Salemba Empat.

Kombih, M. T., \& Suhardianto, N. (2017). Pengaruh aktivitas pemasaran, kinerja keuangan, dan aset tidak berwujud terhadap nilai perusahaan. Ekuitas: Jurnal Ekonomi dan Kenangan, 1(3), 281-302. https://doi.org/10.24034/j25485024.y2017.v1.i3.1 $\underline{909}$

Kuncoro, M. (2009). Metode riset untuk bisnis dan ekonomi, Edisi 3. Jakarta: PT. Gelora Aksara Pratama.

Laili, M., Darmawan, N. A. S., \& Sinarwati, N. K. (2015). Pengaruh debt to equity ratio, kepemilikan manajerial, return on assets, dan current ratio terhadap dividend payout ratio (Studi empiris pada perusahaan manufaktur yang terdaftar di BEI periode 2009-2013). Jurnal Ilmiah Mahasiswa Akuntansi Undiksha, 3(1), 1-11. https://ejournal.undiksha.ac.id/index.php/S1ak/ar ticle/view/5319

Lucyanda, J., \& Lilyana. (2012). Pengaruh free cash flow dan struktur kepemilikan terhadap dividend payout ratio. Jurnal Dinamika Akuntansi, 4(2), 129-138. https://journal.unnes.ac.id/nju/index.php/jda/arti cle/view/2171

Muhammadinah, \& Jamil, M. A. (2015). Pengaruh current ratio, debt to equity ratio, total asset turnover dan return on asset terhadap dividen payout ratio pada perusahaan sektor industri barang konsumsi yang terdaftar di Bursa Efek Indonesia. I-ECONOMICS: A Research Journal on Islamic Economics, 1(1), 1-20. http://jurnal.radenfatah.ac.id/index.php/ieconomi cs/article/view/394

Ningrum, N. (2017). Determinan kebijakan dividen. Jurnal Akuntansi Multiparadigma, 8(3), 499-510. http://dx.doi.org/10.18202/jamal.2017.12.7069

Nurdin, M., Noor, W. K. M. Y., \& Sudirman. (2019). Pengaruh kebijakan keuangan dan tata kelola terhadap pertumbuhan perusahaan (Studi empiris pada industri manufaktur yang listing di Bursa Efek Indonesia 2013-2017). ATESTASI: Jurnal Ilmiah Akuntansi, 2(1), 11-20. https://doi.org/10.33096/atestasi.v2i1.131

Panggabean, R. R., \& Martin, A. (2020). Factors affecting the dividend payout ratio of agriculture and mining companies. Jurnal Akuntansi, 14(1), 46-64. https://doi.org/10.25170/jak.v14i1.949

Pontoh, W. (2015). Signaling, bird in the hand and catering effect in Indonesia. Journal of Life Economics, 2(3), 124. https://doi.org/10.15637/jlecon.80

Pontoh, W. (2018). Pengujian teori pecking order atas struktur modal (Studi pada entitas terbuka di Indonesia). Going Concern: Jurnal Riset Akuntansi, 13(1), 36-39. https://doi.org/10.32400/gc.13.01.18938.2018

Prabulana, R. D., Saiful, \& Suranta, E. (2017). Penentu kebijakan dividen perusahaan yang terdaftar di Bursa Efek Indonesia. Jurnal Fairness, 7(1), 1-14. https://ejournal.unib.ac.id/index.php/fairness/arti cle/view/15141

Puspita, E. (2017). Pengaruh likuiditas, profitabilitas, leverage, dan market ratio terhadap dividend payout ratio pada perusahaan manufaktur. Ekuilibrium: Jurnal Ilmiah Bidang Ilmu Ekonomi, 12(1), 17-35.

http://dx.doi.org/10.24269/ekuilibrium.v12i1.420

Purwanti, D., \& Sawitri, P. (2011). Dampak rasio keuangan terhadap kebijakan deviden. BISMA: Bisnis dan Manajemen, $\quad 3(2), \quad$ 125-134. http://dx.doi.org/10.26740/bisma.v3n2.p125-134

Putry, N. A. C., \& Erawati, T. (2013). Pengaruh current ratio, total assets turnover, dan net profit margin terhadap return on assets. Jurnal Akuntansi, 1(2), 22-34.

https://jurnalfe.ustjogja.ac.id/index.php/akuntansi $\angle$ article/view/13

Rahayu, A. S., \& Hari, M. (2016). Pengaruh current ratio dan quick ratio terhadap kebijakan dividen melalui return on equity pada perusahaan manufaktur yang terdaftar di BEI tahun 2014. Jurnal Ekonomi Bisnis, 21(2), 231-240. http://journal.um.ac.id/index.php/ekobis/article/ view $/ 7435$

Rahayuningtyas, S. (2014). Pengaruh rasio-rasio keuangan terhadap Dividend Payout Ratio (DPR): Studi pada perusahaan yang listing di BEI tahun 2009-2011. Jurnal Administrasi Bisnis, 7(2), 1-9. http://administrasibisnis.studentjournal.ub.ac.id/in dex.php/jab/article/view/326

Rafaizan, R. I., Wardani, D. K., \& Primastiwi, A. (2020). Effect of managerial ownership of companies intellectual capital value as an intervening variable. ATESTASI : Jurnal Ilmiah Akuntansi, 3(1), 28-38. https://doi.org/10.33096/atestasi.v3i1.388

Raza, H., Ramakrishnan, S., Gillani, S. M. A. H., \& Ahmad, H. (2018). The effect of dividend policy on share price: A conceptual review. International Journal of Engineering \& Technology, 7(4.28), 34-39. http://dx.doi.org/10.14419/ijet.v7i4.28.22386

Salsabilla, N. F., \& Isbanah, Y. (2020). Pengaruh profitabilitas dan risiko bisnis terhadap dividend payout ratio melalui likuiditas sebagai variabel moderasi. Jurnal Ilmu Manajemen, 8(4), 1301-1311. https://journal.unesa.ac.id/index.php/jim/article/ view $/ 9606 / 0$

Sarmento, J. D., \& Dana, M. (2016). Pengaruh return on equity, current ratio, dan earning per share terhadap kebijakan dividen pada perusahaan keuangan. E-Jurnal Manajemen, 5(7), 4224-4252. https://ojs.unud.ac.id/index.php/Manajemen/arti cle/view/21252

Sartono, A. (2001). Manajemen keuangan teori dan aplikasi. Yogyakarta: BPFE. 
Sejati, F. R., Ponto, S., Prasetianingrum, S., Sumartono, \& Sumbari, N. N. (2020). Faktor-faktor yang mempengaruhi kebijakan dividen. Berkala Akuntansi dan Keuangan Indonesia, 5(2), 110-131. http://dx.doi.org/10.20473/baki.v5i2.21480

Sulaiman, H., \& Sumani. (2016). Analisis pengaruh likuiditas, leverage, aktivitas, profitabilitas, dan growth terhadap kebijakan dividen emiten yang terdaftar pada Indeks LQ-45 periode 2011-2013. Jurnal Manajemen, 13(2), 179-197. http://ejournal.atmajaya.ac.id/index.php/JM/articl e/view/804

Van Horne, J. C., \& Wachowicz, J. M. (2008). Fundamentals of financial management, $13^{\text {th }}$ Edition. United Kingdom: Pearson Education Limited.

Wahyuni, S. F., \& Hafiz, M. S. (2018). Pengaruh CR, DER dan ROA terhadap DPR pada perusahaan manufaktur di BEI. Jurnal Ekonomi dan Ekonomi Syariah, $1(2)$ $25-42$. https://doi.org/10.36778/jesya.v1i2.18
Wardani, I. A., Isharijadi, \& Astuti, E. (2018). Pengaruh current ratio dan debt to equity ratio terhadap dividend payout ratio perusahaan manufaktur BEI. Forum Ilmiah Pendidikan Akuntansi, 6(2), 1-11. http://prosiding.unipma.ac.id/index.php/FIPA/ar ticle/view/533

Wheelen, T. L., Hunger, J. D., Hoffman, A. N., \& Bamford, C. E. (2018). Strategic management and business policy: Globalization, innovation and sustainability, 15 th Edition. United Kingdom: Pearson Education Limited.

Wijaya, B. I., \& Sedana, I. B. P. (2015). Pengaruh profitabilitas terhadap nilai perusahaan (Kebijakan dividen dan kesempatan investasi sebagai variabel mediasi). E-Jurnal Manajemen, 4(12), 4477-4500. https://ojs.unud.ac.id/index.php/Manajemen/arti cle/view/15500

Yuliyanti, L., \& Nurhasanah, I. (2013). Pengaruh profitabilitas terhadap kebijakan dividen: Kasus pada PT. Bank Central Asia, Tbk. Jurnal Pendidikan Akuntansi dan Keuangan, 1(2), 10-20. https://doi.org/10.17509/jpak.v1i2.15450 